\title{
Reason and Experience in Buddhist Epistemology
}

\author{
CHRISTIAN COSERU
}

\section{Introductory Remarks}

As a specific domain of inquiry, "Buddhist epistemology" (sometimes designated in the specialist literature by the Sanskrit neologism pramannavāda, or the "theory of reliable sources of knowledge") stands primarily for the dialogical-disputational context in which Buddhists advance their empirical claims to knowledge and articulate the principles of reason on the basis of which such claims may be defended. The main questions that we shall pursue here concern the tension between the notion that knowledge is ultimately a matter of direct experience - which the Buddhist considers as more normative than other, more indirect, modes of knowing - and the largely discursive and argumentative ways in which such experiential claims are advanced.

The Sanskrit philosophical idiom, in which Buddhist epistemology finds its first and perhaps most elaborate expression, contains one distinctive term, anubhava, for the concept of "experience" and several terms that closely approximate the concept of "reason." For instance, tarka captures the notion of speculative or logical inquiry; nyāya stands for the notion of rule or method for investigating objects by reliable means; yukti for the notion of ground, proof, or motive, or for something that is right, fit, or appropriate; and hetu for the notion of means by which what was hitherto unproved is now proven. From this cursory terminological survey one may hastily conclude that, whereas the epistemic notion of experience is universal, reason and the corresponding notion of rationality (with their roots in the Latin ratio, which conveys the sense of "reckoning" or "giving an account of judgment," as one might do in court) as a distinctive epistemic faculty or process is not. Of course, this observation assumes a Western frame of reference for examining the relation between reason and experience. An alternative project would be to explore the relation between experience and whatever it is that Buddhists mean when they examine, reflect upon, or seek to prove a given thesis without any reference to Western concepts and ways of thinking. Given that this second

A Companion to Buddhist Philosophy, First Edition. Edited by Steven M. Emmanuel.

(C) 2013 John Wiley \& Sons, Inc. Published 2013 by John Wiley \& Sons, Inc. 
project is well nigh impossible if carried out in a language such as English, whose philosophical vocabulary has been shaped by a longstanding tradition of Western thought, we face a dilemma: can Buddhist philosophy be written in English without losing the explanatory force of its original concepts and categories?

Perhaps setting the problem in terms that are alien to the ways in which the Buddhists have pursued their epistemological reflections showcases a limitation that the tradition in fact does not possess. Since analyses of experience, argumentation, and debate are ubiquitous features of Buddhist thought - barring all caveats about translatability - it should be possible to offer an account of the role that reason and experience play in Buddhist epistemology that is neither inauthentic nor mere reportage. It may also be the case that this distinction between reason and experience is too sharply drawn, and that there are ways of conceiving of what it is like to perceive and reflect that regard them as complementary rather than opposite practices. Indeed, the recent recognition that the exercise of reason varies both over history and across cultures (see Weinberg et al. 2001; Machery et al. 2004; Huebner et al. 2010) should suffice to call into question any attempt to see both practical and theoretical reason as removed from the embodied patterns of conduct that characterize our specific ways of being in the world. As will be argued at length in this chapter, epistemological inquiries in India, particularly with regard to examining the sources of reliable cognition, have never displayed the sort of non-naturalism distinctive to the Cartesian and Kantian traditions in Western philosophy and their characteristically abstract epistemic notions of experience and rationality. Thus, with the return to naturalism in epistemology, hence to understanding cognition in embodied and causal terms, we may now be in a better position to appreciate the contributions of Buddhist philosophers to epistemology.

This chapter explores how the relation between direct experience and discursive modes of knowing is articulated in Indian Buddhism. The first account of this relation, as is well known, originates with Siddhārtha Gautama's experience of enlightenment. This experience becomes at once the source of the Buddhist metaphysical picture of reality and the culmination of all aspiration for genuine knowledge (the kind that guarantees the successful accomplishment of such practical ends as freedom from suffering). Key to this metaphysical picture is the causal principle of dependent arising and a thoroughly psychological account of persons, which takes experience and rational deliberation to be but two of the many contributing factors that shape human identity and agency. Indeed, at the foundation of this Buddhist inquiry into the sources of knowledge is the notion that awakened knowledge has existential consequences, and can effect the removal not only of such afflictions as ignorance and deception but also of the reifying tendencies inherent in common-sense beliefs. It is not surprising, therefore, that epistemological inquiry is central to Buddhist philosophy, and that understanding the nature of knowledge, its sources, and its conditions of possibility are constitutive of its main thrust.

We will start with a brief overview of canonical and Abhidharma perspectives on the scope of epistemological reflection, then evaluate the well-known Madhyamaka skepticism about the possibility of conceptually articulating our specific modes of being in the world, and conclude with an examination of Dignāga and Dharmakīrti's accounts of the relation between observation and inferential reasoning. Lastly, given the modern audience for this essay (and, indeed, for this volume), adopting a constructive, rather 
than merely critical and exegetical approach seems not only appropriate but also timely. If our efforts to reclaim the legacy of non-Western traditions of philosophical inquiry are to have more than a historical or broadly exegetical value (and thus appeal to those outside Buddhist scholarly circles) we must necessarily consider whether Buddhist epistemology can provide a basis for analytic and constructive engagements of the sort typically found in contemporary philosophical debates.

\section{Doubting, Knowing, and Seeing}

In one of his best-known discourses, the Buddha endorses doubt as a legitimate epistemic attitude, telling his disciples that it is fitting to doubt and be perplexed. Enjoining his followers not to accept oral and scriptural tradition, but to rely on personal experience and discernment, the Buddha appears to challenge even such widely accepted modes of inquiry as logical and inferential reasoning: "Do not go by . . logical reasoning, by inferential reasoning, by consideration of reasons, by the reflective acceptance of a view" (Kālāma Sutta). Rather, the Buddha urges, one is to discriminate between wholesome and unwholesome states of mind and use that discrimination as a guide to undertaking only those particular tasks, and following only those specific practices, that are conducive to welfare and happiness. It is nonetheless obvious that, despite such apparent disclaimers of reason, an endorsement of the notion that liberating insight demands careful empirical scrutiny can be clearly gleaned from the canonical literature. Furthermore, the knowledge one gains from such scrutiny must be ascertained on the basis of its effectiveness in removing both afflictive and cognitive obscurations, as well as in overcoming the kind of hindrances typically associated with conditioned phenomena. This emphasis on direct experience as a preferred mode of knowing is one of the reasons why some authors have interpreted the quest for truth in early Buddhism as akin to Western forms of empiricism, even though the Buddhist operates with a wider notion of "experience" than empiricist accounts of knowledge (as derived solely from sense experience) would allow. Thus, contrary to what might seem from afar like a Buddhist endorsement of misology, canonical sources make quite clear that several distinct factors play a crucial role in the acquisition of knowledge. These are variously identified with the testimony of sense experience, introspective or intuitive experience, inferences drawn from these two types of experience, and some form of coherentism, which demands that truth claims remain consistent across the entire corpus of doctrine. Thus, to the extent that Buddhists employ reason, they do so primarily in order further to advance the empirical investigation of phenomena. It is principally for this reason that early Buddhism presents us with a causal account of cognition and takes theories of causation to play a central role in any theory of knowledge. As K. N. Jayatilleke, one of the first proponents of a Buddhist sort of empiricism, notes, "inductive inferences in Buddhism are based on a theory of causation. These inferences are made on the data of perception . . . What is considered to constitute knowledge are direct inferences made on the basis of such perceptions" (Jayatilleke 1963, 457).

But there are matters that are simply not amenable to rational inquiry (and justification), and cannot be offered the sort of categorical answer one would expect of more straightforward issues such as the difference between true and false belief or between 
wholesome and unwholesome mental and affective states. Perhaps the best-known examples of such matters are the so-called unexplained or undetermined (avyākrta) questions: whether the self and the world are eternal or not, whether they are finite or infinite, whether the soul and the body are identical or different, and whether one who has thus gone or come (a tathägata: one who has realized that the real nature of things is just "thus," free from any conceptual imputations) continues, does not continue, both continues and does not continue, or neither continues nor does not continue to exist after death. Modern scholars have proposed different interpretations of the Buddha's apparent non-committal on these crucial metaphysical and epistemological questions. Some claim a philosophical basis for the Buddha's silence, asserting either that he wished to leave the matter open for further inquiry and debate or that he did have answers but refused to reveal them as a deterrent to those seeking to make progress along the path. The canonical literature makes amply obvious that those who are able to follow in the Buddha's footsteps will likewise come to realize that all views are merely conventions established upon common practice, and, as a result, will forgo all philosophical disputation: the adept "agrees with no-one, disputes with no-one, and makes use of philosophical terms without erring" (Dīghanakha Sutta).

We can easily recognize in one of these questions the well-known mind-body problem. Are we to conclude that the Buddha does not consider this to be a real problem, deserving of a careful and measured answer? Or, is it rather the case that our conceptual resources are simply inadequate and cannot provide an answer to these questions in unambiguous and uncontroversial terms? If the knowledge project in Buddhism is about overcoming adherence to mistaken views, then it may well be the case that these questions are simply verbally and conceptually ill-formed, typical examples of pointless speculation (cf. Collins 1982, 132). Phenomena, including the five aggregates that are constitutive of human existence and/or experience (form, feeling, apperception, dispositions, and consciousness), come together as a product of multiple causes and conditions and cease with the removal of these causal and conditioning factors. None of these elements and factors in the web of interdependent arising, however, has causal priority. Any attempt to understand them in terms of permanence or complete dissolution disregards the fundamental causal principle of dependent arising, and therefore is not worthy of serious consideration.

Abhidharma traditions - essentially comprising a large body of literature concerned with examining the received teachings that emerged roughly three centuries after the death of the Buddha - do concede that there are specific principles of reason for why causal chains display patterns of regularity. But even here the assumption is that the descriptive framework of analysis is intended to serve not as a complete metaphysical picture of reality, but as a primer for identifying those elements (thoughts, desires, habitual tendencies) that are unwholesome, with the ultimate aim of overcoming them. The goal is thus pragmatic rather than speculative: unwholesome thoughts and desires must be properly identified and eradicated if liberation from suffering is to be achieved. Attempts to identify specific principles of reason, and indeed to employ them for the purpose of achieving greater clarity about controversial issues, become formalized in such representative works as the Points of Controversy (Kathāvatthu), where we come across issues of doctrinal conflict that warrant serious critical discussion and debate. Whether works such as the Points of Controversy anticipate something like a 
logical system of deductive principles and propositional laws, as early interpreters have claimed (Aung and Rhys Davids 1915; Schayer 2001 [1933]; Bochenski 1961; and Matilal 1998), is less significant for our purpose here than their pragmatic valuation of rational modes of inquiry.

It is true that, in terms of both structure and strategy, these methods aim to codify specific rules of debate, by means of which controversial issues can be addressed and arguments (adduced by both parties) properly weighed and considered. Typically, the debate revolves around such issues as whether all knowledge is analytic, whether one can know the minds of others, whether sensations follow one another continuously, and whether continuity of awareness is genuinely achieved only in meditative equipoise. These debates, which involve a back-and-forth exchange concerning statements of the sort "Is $a b$ ? ("Is knowledge analytic?"), most certainly appeal to principles that are discerningly like forms of material implication, contraposition, and some version of reductio ad absurdum. We may thus recognize these philosophically non-eristic dialogues as "reasoned examinations" (yukti) of controversial points.

The pattern of argumentation at work in Points of Controversy, as Jonardon Ganeri has convincingly shown, is presumptive rather than demonstrative, since the burden of proof switches from one party to the next, neither of which offers any positive thesis (Ganeri 2001, 487). It is precisely this preference for argumentum ad ignorantiam (of the sort: "I am right because not proven wrong") that gains prestige with Nāgārjuna's development of the radical thesis that it is not just that some controversial (or difficult) issues must be rigorously debated, but rather that reality itself in some sense is beyond the reach of conception. Nāgārjuna's skepticism about the possibility of positive argumentation hinges on a crucial insight: that our ordinary ways of conceiving - which depend on such standard concepts and categories as origin, motion, sensation, physical objects and their properties, past, present, and future, and the idea that objects in the class of what J. L. Austin calls "medium-sized dry goods" have a self-standing nature or essence - are seriously flawed. That is, they are the result of a pervasive and systemic ignorance that afflicts the unenlightened human condition.

Before we turn briefly to consider Nāgārjuna's challenge to rationality as a method for establishing positive views, and its implications for Buddhist epistemology, let us first consider the causal aspects of the principles of reason formulated by Abhidharma philosophers.

In the context of addressing such basic doctrinal issues as the nature and scope of Buddhist teachings, Asańga, for instance, identifies four widely shared "reasons" (yukti) for which one may proceed to inquire into the nature of things. The assumption is that such inquiries are indispensable for all who seek knowledge, however it may be defined. The issue under debate is not whether the desire to know itself needs to be called into question - presumably by those who might see it as an affliction, and thus doubt its inherently positive value - but how one who has realized that there are good and perhaps many reasons to examine things is to carry out such examinations. In the Collection on Higher Knowledge (Abhidharmasamuccaya II) (see Tatia 1976), Asanga lists four such reasons. First, there is the principle of dependence (apekșāyukti), which takes into account the fact that conditioned things necessarily arise in dependence upon conditions: it is a principle of reason, for instance, that sprouts depend on seeds. Second, there is the principle of causal efficacy (kāryakāranayukti), which accounts for the 
difference between things in terms of the different causal conditions for their apprehension: it is a principle of reason, thus, that, in dependence upon form, a faculty of vision, and visual awareness, one has visual rather than, say, auditory or tactile experiences (of course, the phenomenon of synesthesia, which Buddhist philosophers did not consider, poses a challenge to this principle). The requirement that any sort of instruction about what must be established as a matter of principle is not contrary to the means by which it can be established captures the sense of the third principle of reason: the realization of evidence from experience (sākșātkriyāsādhanayukti). We realize the presence of water from moisture and of fire from smoke. Lastly, there is the principle of natural reasoning, or the principle of reality (dharmatāyukti), which concerns the phenomenal character of things as perceived (for instance, the wetness and fluidity of water). These four principles of reason become a near permanent fixture with later Indian Buddhist philosophers, and come close to embodying internalist and externalist accounts of rationality for the purpose of justifying certain claims to knowledge (or for appealing to causal explanation). That is, the principles of reason (yukti) capture both the notion of "her reason for doing $x$ " and "the reason $x$ happened" (cf. Kapstein 1988, 153).

This account of the principles of reason could be read in at least two ways: first, as a causal theory of natural fitness, which would postulate that the world is such that it is reasonable to assert that things arise due to specific causes and conditions (for instance, that sprouts come from seeds). Such a theory would share common ground with views expressed by Sanskrit grammarians such as Bhartrihari, who claim that the manner in which words are capable of capturing objects in the empirical domain - such that the thing cognized is in some sense indistinguishable from the word (or expression) by which it is thus cognized - reflects the latter's natural fitness (cf. Iyer 1969, 204). Second, we may understand this account in Kantian terms as describing the a priori conditions for knowledge, since it is reasonable to assume that causal laws justify claims about the order of the objective and subjective domains of experience.

What we have here are examples of natural reasoning or of reasoning from experience, rather than attempts to use deliberative modes of reasoning for the purpose of justifying a given thesis or arguing for its conditions of satisfaction. With Dignāga and Dharmakīrti, such uses of reason, as we shall argue below, develop in what may be best described as a system of pragmatic or context-based reasoning.

\section{Emptiness, Rationality, and the Impossibility of Proof}

The expansive taxonomies of Abhidharma traditions, and their long and detailed lists of the elements of existence and/or experience (dharmas), stand as testimony to the central role that descriptive accounts of experience play in the Buddhist epistemological project. But these descriptive accounts rely on observation, and observation leads to the old philosophical problem of the difference between "seeing" and "seeing as." Recent developments in epistemology, in particular those centered around the project of naturalism, have challenged the empiricist claim that observation is in some sense a type of "seeing" that is always dissociated from "seeing as." As Jerry Fodor, for instance, puts it, letting psychology settle what an observation is, or just letting the observations be 
the data, is legitimate; but "it's sheer Empiricist dogmatism to take it for granted that you can do both at once. In fact, there is no good reason to suppose that the psychological notion of perception - or, indeed, any psychological notion - will reconstruct the epistemological notion of a datum" (Fodor 1991, 200).

For the Buddhist epistemologists, however, this distinction between "seeing" and "seeing as" is instrumental in discriminating conception-free from conception-laden cognitive states, and, indeed, for claiming that only the former warrant the proper label of veridical perception. Typically, the Buddhist points to such examples as being able to attend to perceptual input while thinking of something else, as proof that there is an epistemic gap between direct observation and perceptual judgment. It is this distinction that philosophers such as Nāgārjuna and Candrakīrti challenge, and those such as Dignāga and Dharmakīrti defend as normative for any epistemological project. To say that there is a way that things are that is separate from how they show up to us, and that it is possible to have something like a pure, undiscriminating awareness of phenomena that is implicitly (thought non-discursively) cognitive, is to endorse the view that reality is in effect accessible to thought. The Buddhist epistemologists are not unaware that our cognitive capacities are constrained in some aspects. However, their emphasis is not on the internal and external constraints imposed upon our cognitive systems, but on what can be known and by what means. For Nāgārjuna, though, it is not just that some aspects of reality might escape our discerning capacities, but rather that reality itself is beyond the reach of thought. As he famously puts it in his Stanzas on the Middle Way (Mūlamadhyamakakārikā):

Where the reach of thought turns back, language turns back. The nature of things is, like complete cessation, without origin and without decay.

(MMK.18.7)

For that reason, namely that the truth is deep and difficult to understand, the Buddha's mind despaired of being able to teach it.

(MMK.24.12)

Though at first glance this position might be suggestive of skepticism, it has elicited a wide range of interpretations (some reiterating criticism leveled against Nāgārjuna by his historical rivals, both Buddhist and non-Buddhist, and some reflecting novel and constructive engagements with his philosophy). His position has been variously described as skepticism, nihilism, irrationalism, misology, agnosticism, criticism, dialectic, mysticism, acosmism, absolutism, nominalism, relativism, Wittgenstenian linguistic analysis, philosophical therapy, anti-realism, and deconstructionism, and as articulating a version of paraconsistent logic (see Ruegg 1981; Siderits 1988; Huntington 2007; and Garfield 2008). As these widely divergent readings suggest, the exegetical question about how best to interpret Nāgārjuna's Madhyamaka is yet to be settled. What is indisputable, however, is Nāgārjuna's unambiguous stance vis-à-vis reliance on the common-sense conceptual schema that takes the world to be constituted of enduring, self-sustaining objects.

For the purpose of our analysis, Nāgārjuna appears to raise serious concerns not only about the very notion that there is such a faculty as reason, one attributable to a 
stable and enduring agent, but also about what it is like to be undergoing an experience. Indeed, his dialectical stance calls into question the very notion that our modes of being in the world (and the activities we typically associate with what it is like to see, hear, or verbally comprehend) have something like an inherent existence or character or their own (a svabhāva). The Madhyamaka dialectical project is thus anchored in a deconstructive analysis of key concepts such as causation, essence, and the self. But, for this deconstructive analysis to be effective, Nāgārjuna needs to establish the view of universal emptiness and supply arguments in defense of such a view.

Now, Nāgārjuna does discuss the four modes or sources of knowledge admitted by the Naiyāyikas (perception, inference, cognition of similarity, and verbal testimony), but it seems he is reluctant to commit to the view that such modes of knowing constitute effective epistemic guides. That is, while he recognizes that, say, objects in the empirical domain are established in dependence upon perception, he is less disposed to credit perception with the capacity to disclose entities as ultimately lacking inherent existence. Perception, at best, may be able to establish that objects exist as they appear (though, given the possibility of perceptual illusion, it cannot establish that what has thus appeared has its conditions of ascertainment intrinsically). That is, perception cannot establish by itself whether its contents are veridical or not.

What, then, are some of the ways in which we may explain what our modes of knowing can, if at all, accomplish? Addressing this issue with respect to Nāgārjuna's account, Jan Westerhoff identifies at least three such ways: (1) establishment by mutual coherence; (2) self-establishment; and (3) mutual establishment (Westerhoff 2009, 166). In the first instance, the testimony of experience is corroborated by other means, such as inference. I know that my perception of a blue sky is non-deceptive because I can infer its presence from the absence of clouds or the presence of the sun's warm radiance (given causal relations, or relations of entailment between clouds, sky, and sunlight). Second, it may be that perceptions are in some sense self-revealing. In perceiving I am aware not merely of the object, in this case of the blue sky, but also of my act of perceiving. This view of perception relies on the notion that there is something it is like to see that requires no further corroboration. Finally, it may be the case that perception and object perceived are mutually established: vision discloses a world of visible objects, touch a world of textures, and so on.

Most of Nāgārjuna's efforts are aimed at refuting the self-establishment thesis (though he also briefly considers, and rejects, the mutual coherence thesis) and at justifying the mutual establishment thesis. For Nāgārjuna's opponents, chiefly the Naiyāyikas, the sources of knowledge cooperate in disclosing a world of self-standing, enduring objects, something that, of course, is antithetical to the emptiness thesis. Taking fire, and its capacity to illuminate, as a metaphor for the revealing nature of cognition, Nāgārjuna advances the thesis that phenomena of this sort cannot be established either by perception or by inference. To claim that cognitions are intrinsically self-revealing (just as fire is inherently self-illuminating) is effectively to say that everything knowable is established by some source of knowledge: visible objects are established as such by a faculty of vision. At least in the case of empirical awareness, to know something is to bring it forth and make it manifest to conscious awareness. But Nāgārjuna is not content merely to refute the thesis that, like fire, a mode of knowing, such as perception, discloses both itself and other objects. Rather, he deploys his 
dialectical method to argue that, in effect, a mode of knowing discloses neither itself nor other objects (a double refutation of the opponent's thesis). It is here that Nāgārjuna's conceptual schema, which places objects in mutually exclusive classes, leads to an epistemological impasse: that is, he presents us with an analysis of experience that ignores the difference between what one might deem to be case (on the basis of assumptions about the nature of experience) and what seems actually to be the case in the occurrence of a perceptual event:

A lamp cannot illuminate when it is connected with darkness since their connection does not exist. Why are the lamp and darkness not connected? Because they are opposed. Where the lamp is, darkness is not. How can the lamp remove or illuminate darkness?

(Auto-Commentary to Refutation of Logic (Vaidalyaprakarana-Svavrtti), 24.2-8; in Tola and Dragonetti 1995)

In postulating darkness as something that has the power to conceal, Nāgārjuna in effect appears to reify a phenomenon that is established only negatively: darkness is not something that can be defined as the possessor of some (concealing) capacity in the same way that light is defined by its capacity to illuminate. The phenomenological picture at work here is somewhat inadequate, given that it contains a description of darkness that assumes its discrete existence. Thus, Nāgārjuna's refutation of the capacity of light to illuminate (or, by analogy, of perception to reveal) is problematic, since light and darkness are not independent objects but phenomena within the horizon of intentional awareness. The mutual exclusion of light and darkness, however, is used here not simply to justify the impossibility of light to illuminate what was hitherto concealed; rather, the argument is intended to demonstrate that fire cannot be selfestablished as a source of illumination for other objects (presumably because it is itself dependent on other things, such as fuel). Such self-establishment of illumination in its dual role would require that light and object illuminated stand in a relation of causality. Though Nāgārjuna does admit that darkness is merely the absence of light, he nonetheless appears to argue that absence itself has some kind of positive existence (which perforce prevents it from entering into any causal relationship with light, its opposite).

Against the self-illumination theorist, who postulates that our modes of knowing have a revealing character, the Mādhyamika advances the argument that no mode of knowing has its characteristics intrinsically. Just as a knife cannot cut itself, so also any given mode of knowing cannot know itself in the process of revealing an object. Two principles seem to underlie the Mādhyamika's argument: (i) the anti-reflexivity principle, which postulates that vision does not see itself; and (ii) the doctrine of emptiness, which postulates that vision lacks intrinsic existence (viz., seeing) (cf. Siderits 2003, 32). The argument goes as follows: if seeing is the intrinsic nature of vision, then vision must have seeing intrinsically. Thus, vision must see even in the absence of a visible object, because seeing would otherwise be dependent on external visible objects. But seeing (by definition) requires that there is something that is seen. Hence, in the absence of a visible object, vision itself is what vision sees. But vision cannot see itself (as per the anti-reflexivity principle). Hence, seeing is not the intrinsic nature of vision. Conclusion: it is not true that vision sees visible objects. 
What, then, is it like to have veridical visual experiences, and how might one meaningfully articulate their epistemic status? Neither Nāgārjuna nor his followers offer us a positive answer. For these Buddhist philosophers of the Middle Way, the true nature of reality is such that it is beyond the limits of thought. But we may ask: is it also beyond the reach of experience? And, if it is, by what means may this thesis be ascertained? It is worth noting that Nāgārjuna's categorical stance on the limits of knowledge is decidedly different from such paradoxical inquiry into the possibility of knowledge one comes across, for instance, in Plato's Meno (80d-e). We are dealing here not with the impossibility of inquiring into that which we do not know, but with the impossibility of reaching beyond what inquiry itself can deliver. What we have here is a rejection of the notion that (ultimate) reality can form an object of rational inquiry.

Not all followers of Nāgārjuna are satisfied with his uncompromising stance about the possibility of making assertions about the ultimate nature of reality. As Bhāviveka (who takes seriously the virtues of positive argumentation in discriminating between true and false beliefs) claims, there is something it is like to see the nature of reality, even though only buddhas have such abilities: "Buddhas, without seeing, see all objects of knowledge just as they are, with minds like space and with nonconceptual knowledge" (Verses on the Heart of the Middle Way (Madhyamakahṛdayakārikā), 5.106; in Eckel 2008). The terminology used here includes terms such as āloka (light) and locana (illuminating), both of which convey the sense of vision as having a revealing and disclosing capacity. For the ordinary individual, the clouds that obscure their vision exist only in their minds, since reality is as clear as the autumn sky. Even the experience of enlightenment itself is in some sense associated with a specific type of vision that is effortless in revealing the nature of reality. Such reality cannot be merely the postulate of reason. But Bhāviveka is not only willing to rehabilitate empirical awareness; he also comes to the rescue of reason (even though he admits that inferential knowledge does not possess the kind of vividness that alone qualifies direct experience as a true source of knowledge): "It is impossible to understand reality as an object of inference, but inference can rule out the opposite of the knowledge of reality" (ibid., 5.107). It is this rehabilitation of a reason that is firmly grounded in experience that informs the spartan epistemology of Dignāga and Dharmakīrti, who, as will be examined below, will come to recognize that epistemological inquiries cannot be properly undertaken (or disputes settled) without taking into account that cognitive events are grounded in all aspects of an individual's conscious experience.

\section{Cognitive Events, Logical Reasons, and Causal Explanation}

That reason may be more readily (and effectively) deployed to exclude unwarranted beliefs, rather than to make warranted assertions, marks an important shift in attitude towards the role of rational inquiry. Indeed, the development of Buddhist epistemology as a distinct type of discourse is marked by the gradual acceptance of certain canons of logic and argumentation by those Buddhist philosophers who would come to regard polemical engagement with their Brahmanical opponents as vital to influencing their standing in a wider philosophical community. But there are more than simply sociological reasons at work in this novel orientation towards the scope of rational inquiry. We 
may see this engagement as reflecting a certain eagerness on the part of (at least) some Buddhists to guarantee that their modes of argumentation are commensurable with the widely accepted methods of reasoning formulated by the Naiyāyikas. What seems to concern philosophers such as Dignāga, Dharmakīrti, and their successors is precisely this need to withstand the criticism that core doctrinal principles such as those of momentariness and dependent arising can neither be defended on rational grounds nor find any sort of empirical support.

Debates about the proper way to conduct epistemic inquiries, and about the kind of sources that can provide evidential ground for knowledge, form an integral part of the Indian philosophical traditions. Though there is no universal agreement on what should count as an "accredited" source of knowledge, perception is often singled out as the exception: most philosophers agree that the testimony of direct experience ought to play a central role in any theory of knowledge. For inference and verbal testimony to play the sort of epistemic role that is typically attributed to them, the content of one's mental states (or propositional attitudes) must be grounded in veridical experiences. Indeed, what use would inference have if, in trying to infer the presence of fire from an observation of smoke, one were to mistake dust (or mist) for smoke? But grounding knowledge on a foundation of empirical experience is not without its challenges: perceptual ambiguities are often experienced even under the best conditions of observation, and there is always the possibility of less than optimal perceptual functioning.

How, then, do the Buddhist epistemologists resolve the tension between experience and reasoning? In the first instance, they take perception to function not only as a psychological process, to be understood within the framework of classical Abhidharma phenomenology, but also as an epistemic modality for establishing a cognitive event as knowledge. Secondly, they do not make a radical distinction between epistemology and the psychological processes of cognition, at least not in the Western sense in which modern normative epistemology eschews naturalist explanations. This understanding of epistemology as cognitive theory is most clearly illustrated in Dignāga's formulation of the method of reasoning known as the triple inferential mark (trairūpya), which relies on empirical observation as the most authentic criterion for establishing the validity of inferential cognitions.

What interests us here is not Dignāga's method or its theoretical underpinnings, but the specific way in which he conceives of the relation between reason and experience. For Dignāga (and all subsequent Buddhist epistemologists), cognition operates in two distinct domains: that of particulars, which are only available to empirical awareness, and that of universals, which can only form an object of inferential reasoning:

The sources of knowledge are perception and inference, because the object of cognition has only two characteristics. There is no object of cognition other than the particular characteristic and the universal characteristic, because perception has as its object the particular and inference the universal characteristic of the thing.

(Collection on the Sources of Knowledge (Pramānasamuccaya),

I. 1; in Hattori 1968)

First, unlike Nāgārjuna and his Madhyamaka followers, Dignāga is quite categorical in his assertion that there are reliable sources of knowledge. Furthermore, by offering a phenomenological (thus descriptive) account of cognition, Dignāga makes obvious 
that these two sources of knowledge (roughly equivalent to experience and the exercise of reason) are distinguished not only on the basis of the sort of objects they intend but also in terms of their functional role (cf. Dreyfus 1997, 49). In other words, perception apprehends real individuals by virtue of its constitution (its cognitive architecture and organization: seeing occurs only in organisms endowed with a visual system), whereas inference can apprehend only what are essentially conceptual constructs. This co-presence of perception and object as perceived explains why only perception can enter in a direct causal-cognitive coupling with phenomena in the empirical domain.

Thus, the Buddhist epistemologist comes to regard conception as a secondary, rather than a higher-order cognition: the chasm between the world as experienced and its conceptual apprehension can only be bridged in cognitive events that are pragmatically efficacious. What makes such pragmatic cognitive events "indubitable" is precisely their efficacy, the fact that they attain their object. If the Buddhist epistemologists come to conceive of the relation between reason and experience in context-specific terms, then their epistemology may well be described as a system of pragmatic or contextdependent reasoning. Unlike the deductive systems of semantic reasoning, which are context-free, pragmatic reasoning is generally inductive and encompasses the types of logic (non-monotonic and paraconsistent) that represent reasoning from premises that are context specific (cf. Bell 2001). On this model of pragmatic reasoning, we reason by first observing the occurrence of certain properties in an object or class of objects and the non-occurrence of those same properties when the object is absent. This model of reasoning operates by deriving hypothetical statements from past observations of the inductive domain. Take the example of empirical objects: these are understood to come into existence due to causes and conditions, and thus to be impermanent, for whatever is produced must necessarily cease. Conversely, a permanent object cannot be produced. Propositions of the type "Sound is impermanent, because it is a product," are then true so long as we do not come across an example of permanent (or indestructible) sounds. Shoryu Katsura has defined this type of logic as "hypothetical reasoning based on induction" (Katsura 2007, 76). Assuming this system of reasoning, which is based on the observation and non-observation of evidence, is open to revision so as to accommodate cases where there is a violation of the linguistic convention, we may describe it as a system of context-specific reasoning.

Such appeals to empirical observation tie logical reasoning to the ability to establish causal connections between the things we directly experience. Consequently, exploring the limits of our ability to establish various causal connections between the elements of experience has less to do with principles of logical entailment and more with psychological inquiries into the nature of our perceptual and cognitive systems.

Thus, Dharmakirti's attempt to ground reasoning on a stronger principle than mere observation and non-observation of the evidence would lead him to postulate that there must be some "natural connection" (svabhāvapratibandha) between the thesis and what is to be demonstrated in order to provide a stronger basis for reasoning. This essential connection is meant to overcome the challenge posed by reliance on hypothetical reasoning. However, since Dharmakirti's ultimate criterion for truth is the causal efficacy of cognitions, this essential relation cannot be viewed as pragmatically neutral. Reasoning from the empirical data, so the argument goes, must be grounded 
on more than the simple observation and non-observation of occurring associations and dissociations. In Dharmakīrti's technical vocabulary, the notions of identity (tâdātmya) and causal generation (tadutpatti) thus come to represent two essential conditions on the basis of which we distinguish between theories of meaning and theories of reference. Whereas the truth of the former is contingent upon the semantic content of the sentence, the truth of the latter requires additional empirical knowledge of the causal relation that obtains between the designated objects (cf. Hayes 1988, 254; Arnold 2008, 421).

In order to establish the sort of evidence that can serve as a warrant for sound inference (and to rule out instances of erratic attribution of an essential connection between premises in an argument), Dharmakīrti provides various examples of things that are ordinarily thought of in conjunction: the act of speaking and passion, a living body and breathing, perceptual awareness and the senses, and the stock example of fire and smoke.

But this mode of understanding pragmatic reasoning must explain what sort of properties, whether observed or unobserved, in similar or dissimilar cases, can be counted as evidence for asserting a given thesis? Furthermore, it must also explain how such properties are ascertained. In the case of the act of speaking and passion, for instance, observation of their occurring association is just a case of erratic evidence, for at most the act of speaking can serve as ground for inferring the presence of a speech organ and a capacity to communicate, not of passion. In this example, we see Dharmakīrti indirectly rejecting the notion that speech requires passion - seen as an affliction - for its cause. Obviously, in delivering speeches, buddhas cannot be seen to act from passion or impulse (conditions that afflict only the unenlightened).

Given that observation of one occurring relation does not guarantee the same relation will obtain at a different place and time, how can one escape the risk that there may be unobserved instances to the contrary? For Dharmakīti, appeal to rules of reasoning that best reflect the nature of causally efficient entities (that is, to the so-called natural relation between the properties of an inference) offers the best solution to this conundrum. As he explains, one cannot infer from a cause to its effect, or from a causal totality (kāranasāmagrī) to an effect, because there is always the chance of impending factors preventing the arising of the given effect. One can infer, however, from the effect to the cause, though only in a restricted case. Thus, "only an immediate effect enables the inference of a cause, because it is dependent on it" (Auto-Commentary to Commentary on the Sources of Knowledge (Pramānavārttika-svavrtti), II 12.4; In Pandeya 1989). In this effort to tie reason to causal explanation (and thus view reasons as causes of a certain type), we see the Buddhist epistemologist's concern with maximizing our predictive capacity to make sound inferences, the ultimate goal of which is achieving desired ends.

We have now come full circle in our account of how specific concerns with identifying and formulating principles of reason come to inform the Buddhist epistemological relation between reason and experience. What does it mean, then, to say that there is a natural relation between the properties of an inference, or that the truth of the major premise can be known by perception? It is to put forth a particular view of perception - one that regards empirical awareness as a form of embodied action. To perceive is to understand how we cope with the environment we inhabit. 


\section{Conclusion: Knowledge as Enactive Transformation}

All Indian Buddhist philosophers argue in one way or another for preserving the canonical teachings as conveying a vision of reality that requires constant actualization through a dynamic praxis of interpretation and enactment. This praxis is essentially epistemic in character, marking a gradual progression from the act of listening to, and reflecting upon, a set of statements, to actualizing their significance in an enactive manner. Such dynamic integration of disciplined observation and rational deliberation provides both a pragmatic context and the phenomenological orientation necessary in order to map out the cognitive domain. It is this praxis that leads a representative thinker such as Dharmakirti to claim that the Buddha, whose view he and his successors claim to propound, is a true embodiment of the sources of knowledge. Thus, far from seeing a tension between empirical scrutiny and the exercise of reason, the Buddhist epistemological enterprise positions itself not merely as a dialogicaldisputational method for avoiding unwarranted beliefs, but as a practice aimed at achieving concrete, pragmatic ends. As Dharmakirti reminds his fellow Buddhists, the successful accomplishment of any human goal is wholly dependent on having correct knowledge.

Appealing to the Buddha's extraordinary cognitive abilities, therefore, is a case not of the abdication of reason in the face of authority, but of showcasing the embodied and enactive character of enlightened knowledge. Against the dialectical method of Nāgārjuna, whose ultimate aim is the relinquishing of all views, the Buddhist epistemologists emphasize the critical and positive role of perspicacious reasoning. Indeed, with Dignāga, Dharmakīrti, and their successors, epistemology comes to be regarded as an effective discipline that brings about real results. This is a new epistemology, one that is constrained by the phenomenology of first-person experience rather than by $a$ priori notions about the operations of reason or metaphysical assumptions about the nature of reality.

\section{References}

Arnold, Dan (2008). Transcendental Arguments and Practical Reason in Indian Philosophy. In Argumentation 22, 135-47.

Aung, S. Z., and Rhys Davids, C. A. F. (1915). Points of Controversy, or, Subjects of Discourse: Being a Translation of the Kathāvatthu from the Abhidhammapitaka. PTS translation series no. 5. London: Luzac.

Bell, John (2001). Pragmatic Reasoning: Pragmatic Semantics and Semantic Pragmatics. In Modeling and Using Context: Proceedings of the Third International and Interdisciplinary Conference. Berlin: Springer, 45-58.

Bochenski, J. M. (1961). A History of Formal Logic. Notre Dame, IN: University of Notre Dame Press.

Collins, Steven (1982). Selfless Persons: Imagery and Thought in Theravāda Buddhism. Cambridge: Cambridge University Press.

Dreyfus, Georges (1997). Recognizing Reality: Dharmakìrti's Philosophy and its Tibetan Interpretations. Albany: State University of New York Press. 
Eckel, Malcolm D. (2008). Bhāviveka and His Buddhist Opponents. Cambridge, MA: Harvard University Press.

Fodor, Jerry A. (1991). The Dogma that Didn’t Bark (A Fragment of a Naturalized Epistemology). In Mind 100, 201-20.

Ganeri, Jonardon (2001). Argumentation, Dialogue, and the Kathāvatthu. In Journal of Indian Philosophy 29, 485-93.

Garfield, Jay L. (2008). Turning a Madhyamaka Trick: Reply to Huntington. In Journal of Indian Philosophy 36, 507-27.

Hattori, Masaaki (1968). Dignāga, On Perception. Cambridge, MA: Harvard University Press,.

Hayes, Richard (1988). Dignāga on the Interpretation of Signs. Dordrecht: Kluwer Academic.

Huebner, B., Sarkissian, H., and Bruno, M. (2010). What Does the Nation of China think about Phenomenal States? In European Review of Philosophy 1, 225-43.

Huntington, C. (2007). The Nature of the Mādhyamika Trick. In Journal of Indian Philosophy 35, $103-31$.

Iyer, K. A. Subramania (1969). Bhartṛhari: A Study of the Vākyapadīya in the Light of the Ancient Commentaries. Poona: Deccan College Postgraduate and Research Institute.

Jayatilleke, K. N. (1963). Early Buddhist Theory of Knowledge. London: George Allen \& Unwin.

Kapstein, Matthew (1988). Mi-pham's Theory of Interpretation. In Buddhist Hermeneutics. Ed. Donald S. Lopez. Honolulu: University of Hawai'i Press, 149-74.

Katsura, Shoryu (2007). How Did Buddhists Prove Something? The Nature of Buddhist Logic. In Pacific World Journal 3(9), 63-84.

Machery, E., Mallon, R., Nichols, S., and Stich, S. (2004). Semantics, Cross-Cultural Style. In Cognition 92, B1-B12.

Matilal, Bimal K. (1998). The Character of Logic in India. Ed. J. Ganeri and H. Tiwari. Oxford: Oxford University Press.

Pandeya, Ram Chandra (ed.) (1989). The Pramānavārttikam of Ācārya Dharmakīrti with The Commentaries "Svopajñavrtti" of the Author and "Pramānavārttikavrtti" of Manorathanandin. Delhi: Motilal Banarsidass.

Ruegg, David S. (1981). The Literature of the Madhyamaka School of Philosophy in India. Wiesbaden: Otto Harrassowitz.

Schayer, S. (2001 [1933]) Studies in Indian Logic. Trans. Joerg Tuske. In Indian Logic: A Reader. Ed. J. Ganeri. London: Curzon Press; orig. pubd as Altindische Antizipationen der Aussagenlogik. In Bulletin International de l'Academie Polonaise des Sciences et des Lettres, classe de philologies, 90-6.

Siderits, Mark (1988). Nāgārjuna as Anti-Realist. In Journal of Indian Philosophy 16, 311-25.

Siderits, Mark (2003). Personal Identity and Buddhist Philosophy. Aldershot: Ashgate.

Tatia, Nathman (1976). Abhidharmasamuccaya-bhāṣyaṃ. Patna: K. P Jayaswal Research Institute.

Tola, Ferdando, and Dragonetti, Carmen (1995). Nāgārjuna's Refutation of Logic. Delhi: Matilal Banarsidass.

Weinberg, J., Nichols, S., and Stich, S. (2001). Normativity and Epistemic Intuitions. In Philosophical Topics 29, 429-60.

Westerhoff, Jan (2009). Nāgārjuna's Madhyamaka: A Philosophical Introduction. New York: Oxford University Press. 